\title{
SUBACUTE SCLEROSING LEUCOENCEPHALITIS: AN EPIDEMIO- LOGICAL, CLINICAL AND BIOCHEMICAL STUDY OF 31 CASES
}

\author{
Horácio M. Canelas * \\ ANTôNio B. LefÈvRE *** \\ WALDir A. TOGNOLA **** \\ LINEU C. FonSECA ******
}

\author{
O. Freitas Julião** \\ J. LAMARTINe DE ASSIS *** \\ Francisco B. DE JORGE ***** \\ A. XAVIER-LIMA ******
}

Subacute sclerosing leucoencephalitis (SSLE) is lately deserving the attention of several investigators in what concerns its biochemical, immunological and pathological aspects, these latter including studies by electron microscopy.

Contrasting with a well defined clinical picture, essentially characterized by the binomial consisting of psychiatric disorders and myoclonus or loss of tonus, controversies remain in regard to its pathological background, formerly described either as an inclusion body encephalitis (Dawson ${ }^{5,6}$ ), a panencephalitis (Pette Döring ${ }^{23}$ ) or a subacute sclerosing leucoencephalitis (Van Bogaert ${ }^{29}$ ). The current trend, however, is to take these forms as variants of the same disease $11,18,22,27$ which Tariska ${ }^{26}$ proposed to call subacute progressive panencephalitis. Though we affiliate to the unicist view, the more widely used designation proposed by Van Bogaert will be adopted.

The etiology is still unknown. Nevertheless, some facts point to a viral determination of the disease: 1) presence in the glia and neurons of Cowdry type A intranuclear inclusion bodies $4,16,25$, similar to those found in herpes simplex encephalitis and cytomegaly ${ }^{23}$; 2) intracytoplasmic bodies in the astrocytes, 500 to $800 \AA$ wide, morphologically resembling the viruses, which could signify, however, an abnormal metabolite of the endoplasmic reticulum of the glia cells ${ }^{11}$; since the biologic properties of these inclusion bodies have not so far been demonstrated, the name virion (Caspar et al., cited by Howatson et al. ${ }^{14}$ ) could be extended to them; 3 ) transmission to the monkey through inoculation of biopsic material of human cases (in two

Paper read at the VIIth Neurological Congress of Argentina, held in Buenos Aires in 27-29 October 1966.

* Associate Professor of Neurology, University of São Paulo Medical School; ** Professor of Neurology, University of Campinas Medical School; *** Assistant Professor of Neurology, University of São Paulo Medical School; **** Instructor of Neurology, University of São Paulo Medical School; ***** Chief, Laboratory of the Department of Medicine, University of São Paulo Medical School; $* * * * *$ Instructor of Neurology, University of Campinas Medical School. 


\begin{tabular}{|c|c|c|c|c|c|c|c|c|c|c|c|c|c|}
\hline N & 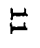 & 능 & 8 & $\infty$ & 9 & ৪ & 哧 & 里 & \& & R & $\rho$ & Case Np & \\
\hline 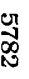 & 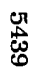 & 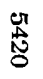 & 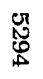 & ֻٓ & $\underset{\infty}{\stackrel{\infty}{\infty}}$ & $\begin{array}{l}\text { లI } \\
\text { 通 }\end{array}$ & $\begin{array}{l}\hat{6} \\
\text { के }\end{array}$ & $\begin{array}{l}\stackrel{\infty}{\infty} \\
\vec{\omega}\end{array}$ & 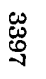 & $\begin{array}{l}\text { ज్ } \\
\underset{\infty}{2}\end{array}$ & : & File No & \\
\hline 多 & 3 & 网 & 网 & 亨 & 3 & $\xi$ & 3 & 3 & 1 & 台 & 多 & $\operatorname{Sex}$ & \\
\hline 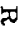 & 2 & 2 & 0 & C & c & a & 20 & G & C & 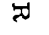 & C & Provenance & \\
\hline ڤั & $\stackrel{5}{\infty}$ & 8 & 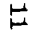 & 워 & है & $\stackrel{\leftrightarrow}{\Delta}$ & N & $\mathscr{E}$ & 㟔 & 5 & $\stackrel{\omega}{\omega}$ & Age (years) & \\
\hline$\Perp_{\infty}^{\Perp}$ & 1 & 1 & | & 1 & ఱ & $\stackrel{9}{9}$ & $\stackrel{\omega}{0}$ & 유 & 8 & 芯 & ध & $\begin{array}{l}\text { Up to death } \\
\text { Up to dismissal }\end{array}$ & $\begin{array}{l}\text { Duration of } \\
\text { the disease } \\
\text { (months) }\end{array}$ \\
\hline+ & + & + & + & + & + & 1 & + & + & + & + & 1 & \multicolumn{2}{|l|}{ Psychiatric disorders } \\
\hline+ & + & + & + & + & + & + & + & + & + & + & + & Myoclonus or loss & of tonus \\
\hline+ & 0 & 0 & 0 & + & + & 1 & + & + & + & 0 & + & Seizures & \\
\hline+ & + & 0 & + & + & + & + & 0 & + & + & + & + & Rigidity & \\
\hline 0 & + & + & + & + & + & + & + & + & + & + & 0 & Babinski sign & \\
\hline 0 & 0 & 0 & 0 & 0 & + & + & 0 & + & 0 & 0 & 0 & C'erebellar signs & \\
\hline 0 & 0 & 1 & + & $\circ$ & 0 & 0 & 0 & 0 & 0 & 0 & 0 & Papilledema & \\
\hline 0 & 0 & 1 & 0 & 0 & + & 0 & 0 & 0 & 0 & + & + & Pallor of disk & $\begin{array}{l}\text { Ophtalmoscopic } \\
\text { disorders }\end{array}$ \\
\hline & 0 & 1 & 0 & 0 & + & 0 & 0 & e & 0 & 0 & 0 & Choroiditis & \\
\hline
\end{tabular}




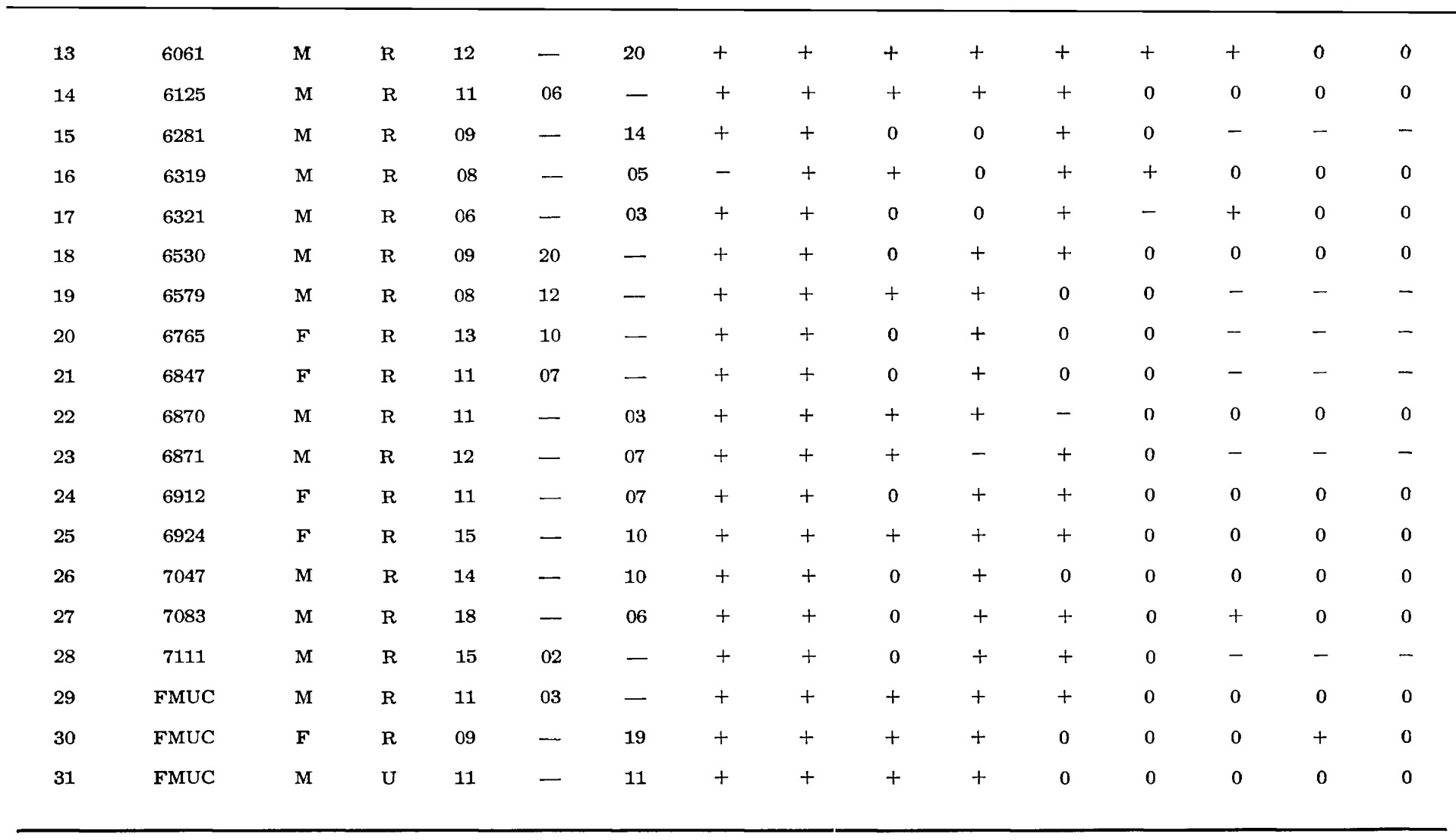

Table 1 - Material and clinical picture. Abbreviations: $R$, rural; $U$, urban; + , presence; 0 , absence; - , doubtful or not investigated. 
animals an encephalitis developed, and in one of them it had the features of SSLE, including the presence of intranuclear inclusion bodies ${ }^{12}$ ); 4) The relationship, in some cases, between the onset of the disease and the death of household animals ${ }^{2,30}$.

Nevertheless, Kolar et al. ${ }^{15}$ give special emphasis to the immunopathologic mechanisms, particularly to the extraneural reticulo-endothelial system in the development of SSLE. These mechanisms would be implicated in the prevalence of the disease in males. On the other hand, the correlation between thymus activity, adolescence, and the prevailing age period of SSLE led Kolar et al. to perform a pneumomediastinography in 7 cases of the disease, a hyperplasia being found in 4 . Evidently, Kolar's hypothesis needs a decisive confirmation and therefore can not refute the arguments in favor of the viral etiology of SSLE.

Electroencephalography and the electrophoresis of the proteins of the cerebrospinal fluid (CSF) and blood are significant aids in the diagnosis of SSLE. The marked increase of CSF gamma-globulins with CSF/blood ratios two or more times greater than the normal figures, seems to be a constant in the disease. Though the immunologic studies are not conclusive yet, those globulins are seemingly produced in situ. The presence of a number of plasma cells in the neuropil of one case studied by Gonatas ${ }^{11}$ was assumed as related to the formation of antibodies.

The questions which still remain to be solved in regard to the etiopathogenesis of SSLE are responsible for the failure of the therapeutic schemes so far tried.

As a contribution to the epidemiological, clinical and biochemical study of SSLE the experience of the Departments of Neurology of the Universities of São Paulo and Campinas Medical Schools will be analyzed*.

\section{MATERIAL AND METHODS}

The clinical material is made up by 31 cases, the first one diagnosed in 1954 (Table 1).

In Tables 2 and 3 the paraclinical criterion used for the diagnosis is summarized. As it can be seen in Table 2, in 16 among 18 cases without postmortem confirmation, alterations of the proteinogram (marked increase of the CSF gammaglobulins, usually with CSF/blood ratios over 1.0) and a typical electroencephalographic pattern were associated. In 2 cases the diagnosis was based on the clinical and electroencephalographic characteristics alone.

* The electroencephalography, the electrophoresis of the CSF and serum proteins, and the pathological aspects will be particularly analyzed by Adail F. Julião, A. Spina-França, and J. Sallum, respectively. A more detailed clinico-pathologic study of the cases of the Department of Neurology of the University of Campinas Medical School will be made by O. Freitas Julião, J. Lopes de Faria, R. Balbo, A. Xavier-Lima, Lineu C. Fonseca and Paulo Bearzotti. 
Regarding the pathological study, intracellular inclusion bodies were found in 8 of 13 cases submitted to postmortem examination. As to the cerebral biopsy, a picture of encephalitis was evidenced in 4 of 7 cases, in one of them inclusion bodies being found. Contrary to what could be expected from the reported prevalence of the lesions in the parieto-occipital region ${ }^{18}$, ${ }^{19}$, encephalitis was found in 3 of the 4 frontal biopsies and in only 1 of the 3 occipital biopsies.

\begin{tabular}{|c|c|c|c|}
\hline & $\begin{array}{l}\text { With postmortem } \\
\text { examination }\end{array}$ & \multicolumn{2}{|c|}{$\begin{array}{c}\text { Without postmortem } \\
\text { examination }\end{array}$} \\
\hline & $\begin{array}{cc}\text { Increase } & \text { Without } \\
\text { of gamma- } & \text { CSF protei- } \\
\text { globulin } & \text { nogram }\end{array}$ & $\begin{array}{l}\text { Increase } \\
\text { of gamma- } \\
\text { globulin }\end{array}$ & $\begin{array}{l}\text { Without } \\
\text { CSF protei- } \\
\text { nogram }\end{array}$ \\
\hline \begin{tabular}{l|l} 
EEG & $\begin{array}{l}\text { Typical } \\
\text { Atypical or not performed }\end{array}$
\end{tabular} & $\begin{array}{ll}7 & 1 \\
2 & 3\end{array}$ & $\begin{array}{r}16 \\
0\end{array}$ & $\begin{array}{l}2 \\
0\end{array}$ \\
\hline Table $2-F$ & \multicolumn{3}{|c|}{ Paraclinical criterion of diagnosis. } \\
\hline Electroencephalogram & $\begin{array}{l}\text { Typical } \\
\text { Atypical }\end{array}$ & & $\begin{array}{r}28 \\
3\end{array}$ \\
\hline $\begin{array}{l}\text { Electrophoresis of } \mathrm{CSF} \\
\text { proteins }\end{array}$ & \multicolumn{2}{|c|}{$\begin{array}{l}\text { Increase of gammaglobulin } \\
\text { Normal }\end{array}$} & $\begin{array}{r}25 \\
0\end{array}$ \\
\hline $\begin{array}{l}\text { Intracellular inclusions (post- } \\
\text { mortem examination) }\end{array}$ & \multicolumn{2}{|l|}{ Present } & 8 \\
\hline \multirow{2}{*}{ Cerebral biopsy } & Encephalitis & $\begin{array}{l}\text { Frontal } \\
\text { Occipital }\end{array}$ & $\begin{array}{l}3 \\
1\end{array}$ \\
\hline & Normal & $\begin{array}{l}\text { Frontal } \\
\text { Occipital }\end{array}$ & $\begin{array}{l}1 \\
2\end{array}$ \\
\hline
\end{tabular}

Table 3 - Data with diagnostic significance.

\section{RESULTS AND COMMENTS}

Age - The mean age was 11.7 years, with the limits of 3 and 22 years (fig. 1); this upper limit is seldom recorded in the literature ${ }^{20,31}$. In 27 patients the age varied between 6 and 15 years. These findings agree with those of Canal and Torck ${ }^{2}$ ( $75 \%$ of their patients were from 6 to 12 years old, with a mean age of 9.1 years) and Hamoen et al. ${ }^{12}$ (in $50 \%$ of their cases the disease started between 6 and 8 years of age). 


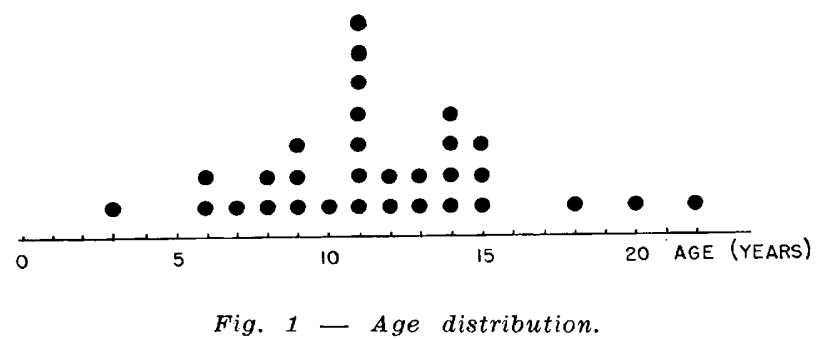

Sex - Males prevailed markedly over females, in a rate very similar to the figures reported by several authors (Table 4) but much higher than the general sex distribution in the outpatient service (Table 5).

\begin{tabular}{|c|c|c|c|c|}
\hline \multirow{2}{*}{ Author } & \multirow{2}{*}{ Country } & \multicolumn{2}{|c|}{$\operatorname{sex}$} & \multirow{2}{*}{$\begin{array}{c}\text { Percentage } \\
\text { of male } \\
\text { patients }\end{array}$} \\
\hline & & Male & Female & \\
\hline Canal and Torck" & Belgium & 60 & 18 & 76.9 \\
\hline Osetowska and Torck ${ }^{20}$ & Belgium-Poland & 51 & 19 & 72.9 \\
\hline Kolar et al. ${ }^{15}$ & Czechoslovakia & 47 & 20 & 70.1 \\
\hline Lorand et al. ${ }^{18}$ & Hungary & 30 & 18 & 62.5 \\
\hline Hamoen et al. ${ }^{12}$ & The Netherlands & 17 & 6 & 73.9 \\
\hline Usunoff et al. ${ }^{27}$ & Bulgaria & 16 & 3 & 84.2 \\
\hline Present series & Brazil & 23 & 8 & 74.2 \\
\hline
\end{tabular}

Table 4 - Incidence of subacute sclerosing leucoencephalitis according to sex.

\begin{tabular}{llccc}
\hline & & $\begin{array}{c}\text { No. of } \\
\text { cases }\end{array}$ & Percentage & $\begin{array}{c}\text { General percentage in } \\
\text { the outpatient section }\end{array}$ \\
\hline \hline \multirow{2}{*}{ Sex } & Male & 23 & 74.2 & 58.0 \\
Race & Female & 8 & 25.8 & 42.0 \\
Provenance & White & 31 & 100.0 & 83.0 \\
& Urban & 7 & 22.6 & 65.0 \\
\hline
\end{tabular}

Table 5 - Sex, race and provenance of 31 cases of subacute sclerosing encephalitis. 
Race - All patients were white.

Provenance - Patients coming from rural zones were more afflicted $(77,4 \%)$ than those living in large cities, in a rate completely opposite the general distribution in the outpatient service (Table 5). Most of cases lived in hinterland counties 'with low demographic density, a fact also found by Canal and Torck ${ }^{2}$ in Belgium, and by Glasgow and Wrighton (apud Canal and Torck ${ }^{2}$ ) in New Zealand.

Geographic distribution - The distribution of cases in the State of São Paulo and in the North of the State of Paraná (a region intimately bound to the State of São Paulo) was scattered, though some prevalence could be noted in the Western region (fig. 2). Canal and Torck ${ }^{2}$ found a predominance of cases of SSLE coming from the Northern and Western regions of Belgium, which present significant geographic differences, especially concerning altitude.

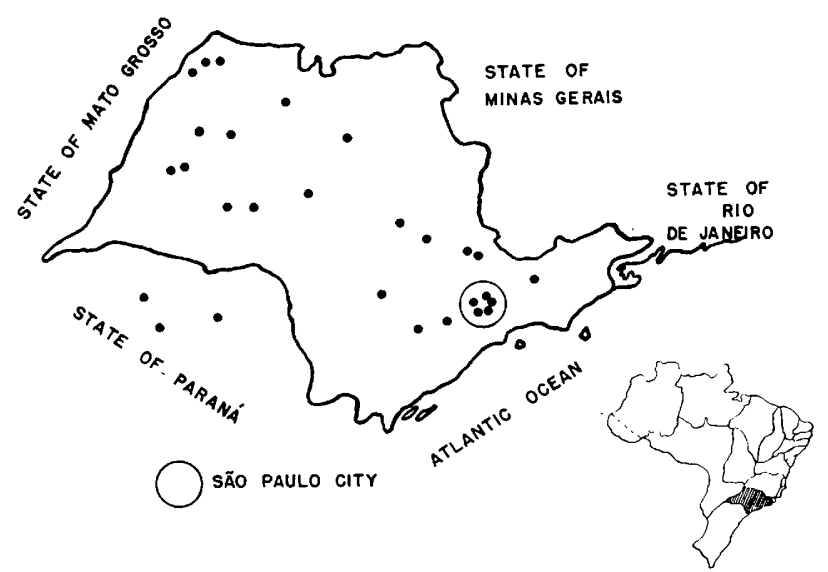

Fig. 2 - Geographic distribution.

There are no studies on the frequency and distribution of cases of SSLE in other States of Brazil. Most of the cases studied in the State of Guanabara (actually a large city and not a state), however, came from the suburban zones ${ }^{1}$.

Climate and seasons - No correlation between incidence of SSLE and climate could be stated.

Like Canal and Torck'2 and Usunoff et al. ${ }^{27}$, no seasonal prevalence of the onset of the disease was found (Table 6).

Average duration of the disease - In 16 patients followed up to death, the average duration of the disease was 7 months, with a range from 2 to 20 
months. Hamoen et al. 12 found an average of 13 months and a range from 3 to 27 months. Usunoff et al. ${ }^{27}$ report the range from 3.5 to 18 months. Lehmannn and Ule ${ }^{17}$ found a significant correlation between age and duration of the disease; in our material, however, a non significant negative correlation was found $(\mathrm{r}=-0.376 ; \mathrm{tr}=1.518)$.

\begin{tabular}{lc}
\hline Season & No. of cases \\
\hline \hline Summer & 8 \\
Autumn & 7 \\
Winter & 7 \\
Spring & 9 \\
& \\
\hline \multirow{2}{*}{ Table 6 - Seasonal distribution of the }
\end{tabular}

Clinical picture - In the symptomatology (Table 7) the constancy of myoclonus or losses of tonus, and psychiatric disorders was evidenced. The losses of tonus can not be clinically distinguished from myoclonus, and it is also hard to decide on the existence of lapses of consciousness. Myoclonus occurred as the first symptom in $35.5 \%$ of cases (fig. 3), a rate very similar to those reported by Usunoff et al. ${ }^{28}$ (a third of the cases) and Hamoen et al. ${ }^{12}(30.4 \%)$.

\begin{tabular}{lcc}
\hline & No. of cases * & Percentage \\
\hline \hline Psychiatric disorders & $28: 28$ & 100.0 \\
Myoclonus or loss of tonus & $31: 31$ & 100.0 \\
Seizures & $15: 31$ & 48.4 \\
Babinski sign & $22: 30$ & 73.3 \\
Rigidity & $25: 30$ & 83.3 \\
Cerebellar signs & $5: 31$ & 16.1 \\
\hline
\end{tabular}

Table 7 - Neurological manifestations. * Rate between presence of the manifestation and number of cases in which it could be availed.

In 3 cases the existence of psychiatric alterations could not be stated, owing to doubtful or lacking anamnestic data. Concerning this aspect, Hasaerts and Van Geertruyden ${ }^{13}$ stress the difficulty sometimes found in settling the 


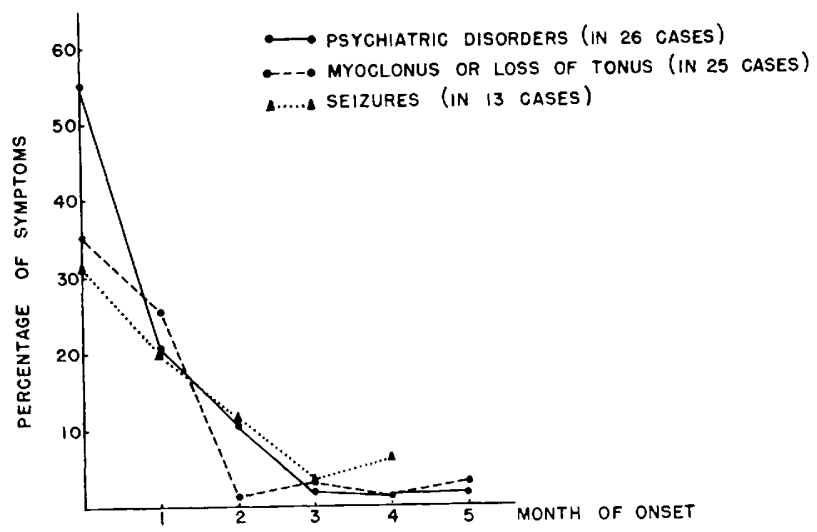

Fig. 3 - Onset of symptoms up to the fifth month.

pathologic character of the initial psychiatric manifestations. These occurred as the first symptom of the remaining 28 patients in a proportion of $55.6 \%$ and, up to the fifth month of disease, they were manifest in the great majority of cases. In Usunoff et al.'s ${ }^{28}$ series (45 cases) psychiatric disorders were the first symptom in two thirds of the cases.

Grand mal seizures occurred in $48.4 \%$ of the patients. In $33.3 \%$ of the cases they were the first symptom, a rate very greater than that reported by Usunoff et al. ${ }^{28}(6.6 \%)$. The high figure we found may be due to the fact that the parents or relatives could have overlooked the other symptoms, particularly the initial psychiatric disorders.

Muscle hypertonus occurred in $83.3 \%$ of the cases during the course of the disease. Usually an extrapyramidal stiffness was evidenced but it ultimately evolved to a decerebrate or decorticate rigidity, whose onset was coindent with the subsidence of the hyperkinesis.

Ataxia was somewhat rare, in spite of the frequency of involvement of the cerebral pathways seen at the pathological examination. The pyramidal lesion (the Babinski sign was found in $73.3 \%$ of the cases) could be responsible for this clinico-pathologic disagreement .

\begin{tabular}{lrr}
\hline \hline Edema of the optic disk & 4 & 16.7 \\
Pallor of the optic disk & 3 & 12.5 \\
Choroiditis plus pallor of the disk & 1 & 4.2 \\
Normal fundus oculi & 15 & 62.5 \\
\hline
\end{tabular}


The ophtalmoscopic examination disclosed alterations in a third of cases (Table 8), consisting of a slight edema or pallor of the optic disk; in one case there was choroiditis associated with pallor. Osetowska and Torck ${ }^{20}$ found edema or pallor of the disk, or else retinitis pigmentosa, in $37 \%$ of the cases.

In cases 30 and 31 the onset of the disease was concomitant with an epizoctic in household chicken. Seemingly this kind of relationship could be detected in other patients provided we had not directed our attention to his question only in the last cases of our series.

Copper, ceruloplasmin, magnesium and sulfur concentrations in the blood serum (Table 9) - The determinations of the total blood copper in 8 cases always showed high contents, ranging from 123 to $310 \mu \mathrm{g} / 100 \mathrm{ml}$ (mean 210 $\mu \mathrm{g} / 100 \mathrm{ml}$ ), associated with slight changes in the ceruloplasmin levels; this finding suggests that the hypercupremia is consequent to increment of the free copper. These results agree with those of Cernacek et al. ${ }^{3}$, who found in 13 cases of SSLE an average blood copper content of $206 \mu \mathrm{g} / 100 \mathrm{ml}$, significantly higher than the levels in 12 normal controls.

\begin{tabular}{|c|c|c|c|c|}
\hline Case No. & $\begin{array}{l}\text { Copper } \\
(\mu \mathrm{g} / 100 \mathrm{ml})\end{array}$ & $\begin{array}{l}\text { Ceruloplasmin } \\
\qquad(\mathrm{mg} / 100 \mathrm{ml})\end{array}$ & $\begin{array}{l}\text { Magnesium } \\
(m E q / l)\end{array}$ & $\begin{array}{c}\text { Sulfur } \\
(m g / 100 \mathrm{ml})\end{array}$ \\
\hline 11 & 158 & - & 1.760 & - \\
\hline 12 & 129 & 27.9 & 2.370 & - \\
\hline 15 & 181 & - & 一 & - \\
\hline 16 & 一 & 39.6 & 1.716 & 一 \\
\hline 20 & 259 & 38.0 & 一 & - \\
\hline 24 & 123 & 37.0 & 2.579 & 2.220 \\
\hline 26 & 246 & 43.4 & 2.995 & 2.066 \\
\hline 27 & 310 & 42.5 & - & - \\
\hline 28 & 271 & 36.0 & 2.659 & 2.050 \\
\hline Mean & 210 & 37.8 & 2.346 & 2.112 \\
\hline Method & $\begin{array}{l}\text { Diethyldithio- } \\
\text { carbamate }\end{array}$ & Houchin & Yellow titan & Turbidimetric \\
\hline $\begin{array}{l}\text { Normal } \\
\text { range : }\end{array}$ & $90-125(8)$ & $27.4-39.8(7)$ & $1.916-2.185(9)$ & $0.800-1.545 \quad(10)$ \\
\hline
\end{tabular}

Table 9 - Total copper, ceruloplasmin, magnesium and sulfur concentrations in the blood. * References into parentheses. 
The blood levels of sulfur, determined only in 3 cases, were high. The blood concentrations of magnesium showed a variable behavior, in 4 cases being over and in 2 being under the normal limits.

\section{SUMMARY}

Thirty-one cases of SSLE are reported. The diagnosis was based on the clinical picture, the marked increase of gammaglobulins in the cerebrospinal fluid, the typical electroencephalographic pattern, and the pathological examination. Intracellular inclusion bodies were found at the postmortem examination of 8 among 13 cases and in 1 of 7 cerebral biopsies. The mean age was 11.7 years, with the limits of 3 and 22 years. Males prevailed markedly over females $(23: 8)$. Patients from rural regions were the bulk of the series $(77.4 \%)$. No definite regional predominance was demonstrated by the analysis of the geographic distribution. A seasonal influence was not evidenced. In 16 patients followed up to death, the average duration of the disease was 7 months, with a range from 2 to 20 months. In the clinical picture the constancy of myoclonus or losses of tonus, and psychiatric disorders was evidenced. The first symptom was the psychiatric alteration in $55.6 \%$ of the cases, myoclonus in $35.5 \%$ and grand mal seizures in $33.3 \%$. Rigidity and pyramidal signs were very frequent, while the cerebellar syndrome was rare. Ophtalmoscopic alterations (edematous or pale disk, choroidits) were found in a third of the cases. In two cases an epizootic of household chicken was coincident with the onset of the disease. The blood copper concentrations determined in 8 cases were always above the normal range, while ceruloplasmin remained within the normal limits. The blood sulfur levels were high in 3 patients studied. The blood magnesium levels were variable in 6 patients studied.

\section{RESUMO}

Leucoencefalite esclerosante subaguda: estudo epidemiológioco, clínico e bioquímico de 31 casos

São apresentados 31 casos de leucoencefalite esclerosante subaguda, cujo diagnóstico se baseou no quadro clínico, no acentuado aumento das globulinas $\gamma$ no líquido cefalorraqueano, nas características alterações do eletrencefalograma e no estudo anátomo-patológico. Foram encontrados corpúsculos de inclusão intracelular mediante o estudo necroscópico de 8 entre 13 casos e o exame histopatológico de 1 entre 7 biopsias cerebrais. A média etária foi de 11,7 anos, com os limites de 3 a 22 anos. O sexo masculino predominou nitidamente sôbre o feminino $(23: 8)$. Os pacientes provenientes da zona rural constituíram a maioria dos casos $(77,4 \%)$. A análise da distribuição geográ- 
fica não demonstrou predomínio regional definido. Não foi observada influência estacional sôbre o inicio da moléstia. Em 16 casos acompanhados até o óbito, a duração média foi de 7 meses, com uma faixa de 2 a 20 meses. No quadro clínico sobressaiu a presença constante de mioclonias ou perdas de tono, e de alterações psiquicas. $O$ primeiro sintoma foi representado por distúrbios psíquicos em 55,6\% dos pacientes, por mioclonias em $35,5 \%$ e por convulsões do tipo grande mal em $33,3 \%$. Rigidez e sinais piramidais foram muito freqüentes, sendo rara a sindrome cerebelar. Alterações oftalmoscópicas (edema ou palidez de papila, coroidite) foram verificadas em um têrço dos casos. Em 2 casos o início da moléstia coincidiu com uma epizootia de galinhas. Os valôres do cobre sangüíneo, determinados em 8 casos, situaram-se sempre acima da faixa normal, enquanto a ceruloplasmina permaneceu dentro dos limites normais. Os valôres do enxôfre sangüineo revelaram-se elevados em 3 pacientes examinados. Os niveis da magnesemia mostraram-se variáveis em 6 pacientes estudados.

\section{REFERENCES}

1. AlenCAR, A. A. - Personal communication. São Paulo, October 1966.

2. CANAL, N. \& TORCK, P. - An epidemiological study of subacute sclerosing leucoencephalitis in Belgium. J. neurol. Sci. 1:380-389, 1964.

3. CERNACEK, J.; KOBSA, K.; BRACHTLOVA, M. \& MAJEROVA, A. - Serum-copper level in subacute sclerotisant leukoencephalitis. Psychiat. Neurol. 147: 321-326, 1964.

4. COWDRY, E. V. - The problem of intranuclear inclusions in virus diseases. Arch. Path. (Chic.) 18:527-542, 1934.

5. DAWSON, J. R. - Cellular inclusions in cerebral lesions of lethargic encephalitis. Amer. J. Path. 9:7-16, 1933.

6. DAWSON, J. R. - Cellular inclusions in cerebral lesions of epidemic encephalitis (second report). Arch. Neurol. Psychiat. (Chic.) 31:685-700, 1934.

7. De JORGE, F. B. \& CANELAS, H. M. - Contribuição ao estudo da ceruloplasmina. I: Valôres normais no sôro sangüineo. Arq. Neuro-psiquiat. (S. Paulo) 22:271-276, 1964.

8. De JORGE, F. B.; CANELAS, H. M. \& SPINA FRANÇA, A. - Contribuicão ao estudo do metabolismo do cobre. II: Valôres normais de cobre no sangue, líquido cefalorraqueano e urina. Rev. paul. Med. 62:125-128, 1963.

9. De JORGE, F. B.; CANELAS, H. M. \& ZANINI, A. C. - Metabolismo do magnésio. II: Valôres normais no sôro, plasma, sangue total, líquido cefalorraqueano, urina e fezes. Rev. paul. Med. 65:95-105, 1964.

10. De JORGE, F. B.; CANELAS, H. M. \& ZANINI, A. C. - Metabolismo do enxôfre. II: Valôres normais no sôro sangüíneo, liquido cefalorraqueano, saliva, urina e fezes. Rev. paul. Med. 65:332-339, 1964. 
11. GONATAS, N. K. - Subacute sclerosing leucoencephalitis: electron microscopic and cytochemical observations on a cerebral biopsy. J. Neuropath. 25: 177-201, 1966.

12. HAMOEN, A.-M.; HERNGREEN, H.; STORM VAN LEEUWEN, W. \& MAGNUS, O. - Encéphalite subaiguë progressive: constatations cliniques et electroencéphalographiques dans 23 cas. Rev. neurol. 94:109-119, 1956.

13. HASAERTS, E. \& VAN GEERTRUYDEN, E. - Caractères et étapes de la détérioration psychique dans la leuco-encéphalite sclérosante subaiguë (14 observations). Encéphale 47:31-72, 1958.

14. HOWATSON, A. F.; NAGAI, M. \& ZU RHEIN, G. M. - Polioma-like virions in human demyelinating brain disease. Canad. med. Ass. J. 93:379-386, 1965.

15. KOLAR, O.; MUSIL, J. \& FUNTALOVA, M. - A contribution to problems of sexual difference in susceptibility to subacute sclerosing leucoencephalitis. Acta neurol. psychiat. belg. 66:732-741, 1966.

16. KURTZKE, J. F. - Inclusion body encephalitis: a nonfatal case. Neurology (Minneap.) 6:371-376, 1956.

17. LEHMANN, H.-J. \& ULE, G. - Subakute Encephalitisformen unbekannter Ätiologie: über die nosologische Stellung der Leukencephalitis (van Bogaert) und der Panencephalitis (Pette-Döring). Arch. Psychiat. Nervenkr. 206:356-366, 1964.

18. LORAND, B.; NAGY, T. \& TARISKA, S. - Subacute progressive panencephalitis. Wld Neurol. 3:376-394, 1962.

19. OSETOWSKA, E. - The distribution of telencephalic lesions in subacute sclerosing leucoencephalitis (pathological examination of 50 cases). In Van Bogaert, L.; Radermecker, J.; Hozay, J. \& Lowenthal, A.: Encephalitides. Elsevier, Amsterdam, 1961, pp. 414-469.

20. OSETOWSKA, E. \& TORCK, P. - Subacute sclerosing leukoencephalitis: analysis of complementary features. Wld Neurol. 3:566-579, 1962.

21. PELC, S.; PERIER, J.-O. \& QUERSIN-THIRY, L. - Résultats expérimentaux obtenus dans l'encéphalite humaine, type encéphalite subaiguë à inclusion, leuco-encéphalite sclérosante subaiguë. Rev. neurol. 98:3-24, 1958.

22. PETSCHE, H.; SCHINKO, H. \& SEITELBERGER, F. - Neuropathological studies on Van Bogaert's subacute sclerosing leucoencephalitis. In Van Bogaert, L.; Radermecker, J.; Hozay, J. \& Lowenthal, A.: Encephalitides. Elsevier, Amsterdam, 1961, pp. 353-385.

23. PETTE, H. \& DORING, G. - über einheimische Panencephalomyelitis vom Charakter der Encephalitis japonica. Dtsch. Z. Nervenheilk. 149:7-44, 1939.

24. SCHIOTT, C. R. - On the significance of inclusion bodies in subacute encephalitis. In Van Bogaert, L.; Radermecker, J.; Hozay, J. \& Lowenthal, A.: Encephalitides. Elsevier, Amsterdam, 1961, pp. 410-413.

25. SEITELBERGER, F. - Subacute sclerosing leucoencephalitis: contribution to the histopathology of Van Bogaert's subacute sclerosing leucoencephalitis. In Van Bogaert, L.; Radermecker, J.; Hozay, J. \& Lowenthal, A.: Encephalitides. Elsevier, Amsterdam, 1961, pp. 340-352. 
26. TARISKA, S. - The vasal mechanisms responsible for the pathological variations of subacute progressive panencephalitis. In Van Bogaert, L.; Radermecker, J.; Hozay, J. \& Lowenthal, A.: Encephalitides. Elsevier, Amsterdam, 1961, pp. 541-559.

27. USUNOFF, G.; BOJINOV, S. \& GUEORGUIEV, I. - L'encéphalite progressive hypercinétique subaiguë chez l'enfant, en Bulgarie. Acta neurol. psychiat. belg. 57:913-922, 1957.

28. USUNOFF, G.; BOJINOV, S. \& GUEORGUIEV, I. - Discussion on the subacute sclerosing encephalitides of Dawson, Pette-Döring and Van Bogaert. In Van Bogaert, L.; Radermecker, J.; Hozay, J. \& Lowenthal, A.: Encephalitides. Elsevier, Amsterdam, 1961, pp. 501-508.

29. VAN BOGAERT, L. - Une leuco-encéphalite sclérosante subaiguë. J. Neurol. Neurosurg. Psychiat. 8:101-120, 1945.

30. VAN BOGAERT, L. - Leuco-encéphalite sclérosante subaiguë. Encyclopédie Médico-Chirurgicale, Système Nerveux. Editor unknown, Paris, 1960, $17051 \mathrm{C}^{10}$.

31. WENDER, M. - Leucoencéphalite sclérosante subaiguë de l'adulte. Rev. neurol. 97:285-294, 1957. 